\title{
AOR
}

Selected Papers of \#AolR2019: The $20^{\text {th }}$ Annual Conference of the Association of Internet Researchers Brisbane, Australia / 2-5 October 2019

\section{\#RESISTHUDUMANAMBA: KENYAN GOVERNMENT AT A CROSSROAD}

Job Mwaura, Doctoral Fellow, Department of Media Studies, University of the Witwatersrand, Johannesburg, South Africa

\section{Introduction}

In the past few years, Kenya's digital landscape has transformed and this has been made possible by proliferation of the usage of digital technologies. Recently, the government rolled out a National Integrated Identity Management System (NIIMS) which is meant to capture biometric and geographical data (GPS). Biometric data in this case include fingerprints, hand geometry, earlobe geometry, retina and iris patterns, voice waves and Deoxyribonucleic Acid (DNA) among other things in digital form. The mandatory registration will generate a unique identifier for every citizen called Huduma Number (Service number).

The introduction of this Huduma Number has generated uproar amongst citizens both in online and offline spaces and a campaign dubbed \#ResistHudumaNamba emerged. This paper will therefore examine the following issues: What has contributed to the decline of trust, if any, between the government and its citizens when digital technologies are involved? What are the actual sentiments given for and against in the introduction of Huduma Number? What are the underlying reasons for continued digital registration of Kenyans?

\section{Data ownership in Kenya}

Telecommunication companies in Kenya, such as Safaricom are the largest owners of consolidated data in Kenya on Kenyans. This is data is captured in SIM card registration and in the security CCTV project Safaricom was contracted to do by the government. The government on the other hand has been trying in the last few years to not only own data but also use data for e-governance. Various laws have been amended and new ones created to cater for these digital developments.

\section{Methods}

This research will be a qualitative research study. Data was generated from social media sites (Twitter and Facebook), as well as blog posts and newspaper articles. A discourse analysis of the events around \#ResistsHudumaNamba in these sources was done so as to answer the research questions. Twitter data from (15 $5^{\text {th }} \mathrm{Feb}-27^{\text {th }}$ Feb 2019) with hashtag \#ResistHudumaNamba was scrapped using TAGs and the initial analysis, including data clean-up was done using Nvivo software. Data from blogposts, newspaper articles and relevant government documents was also analysed. 


\section{AOR}

Selected Papers of \#AolR2019: The $20^{\text {th }}$ Annual Conference of the Association of Internet Researchers Brisbane, Australia / 2-5 October 2019

\section{Thematic Analysis of Discourses on \#ResistHudumaNamba}

In the \#ResistHudumaNamba online campaign, several reasons emerged from the online discussion as the reason why citizens called resistance to register for the new identity system.

\section{Corruption}

A series of corruption within the government has been a common thing and citizens were getting fed up with them. In the case of Huduma Namba as a government project, it flaunted all the procurement laws since there was no adequate needs assessment, planning and budgeting did not undergo public participation. According to media sources the piloting phase of this project required 6 billion Kenya shillings (About USD 60 million). The government was not clear on how much more was used during the actualization of the project that was activated worldwide. Basic procurement stages involve Pre-tendering phase, tendering phase and Post tendering phase.

Huduma Namba required procurement of registration gadgets and personnel. None of these underwent any procurement procedure as stipulated in Procurement Act and Finance Act of Kenya. The repercussions of not procuring the gadgets came to light much later.
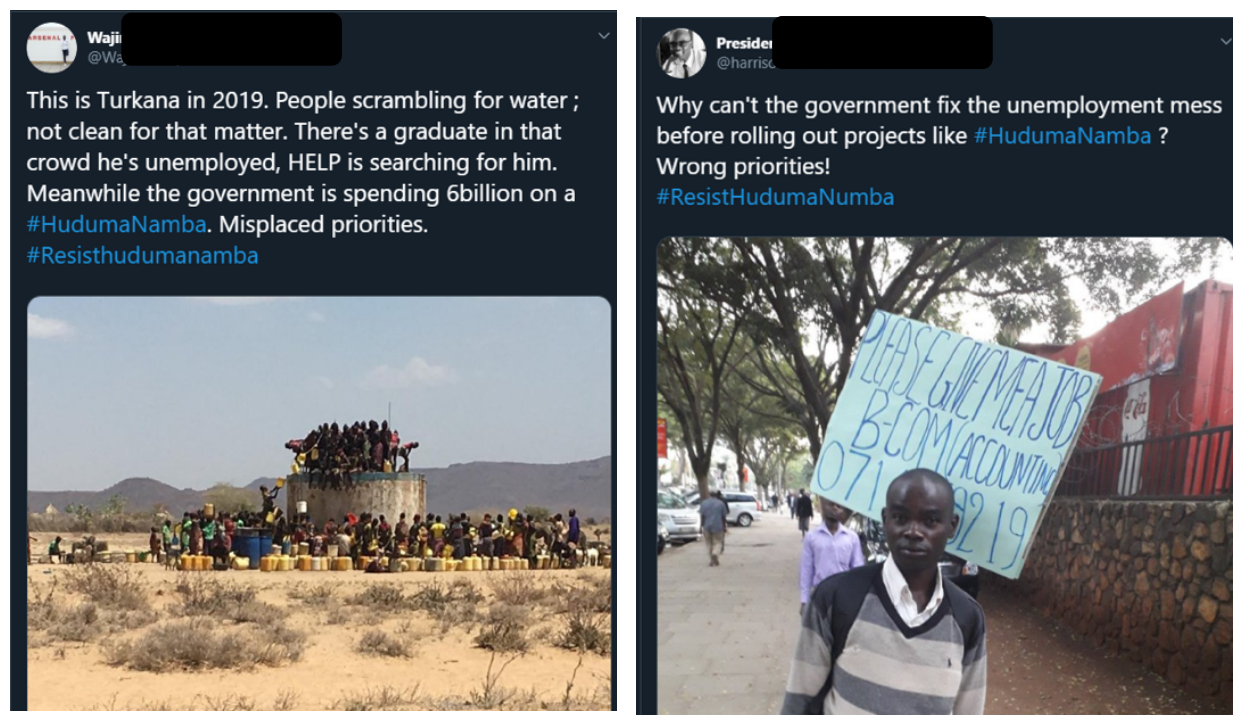

Suggested Citation (APA): Mwaura, J. (2019, October 2-5). \#ResistHudumaNamba: Kenyan Government at a Crossroad. Paper presented at AolR 2019: The $20^{\text {th }}$ Annual Conference of the Association of Internet Researchers. Brisbane, Australia: AolR. Retrieved from http://spir.aoir.org. 


\section{AOR}

Selected Papers of \#AolR2019: The $20^{\text {th }}$ Annual Conference of the Association of Internet Researchers Brisbane, Australia / 2-5 October 2019
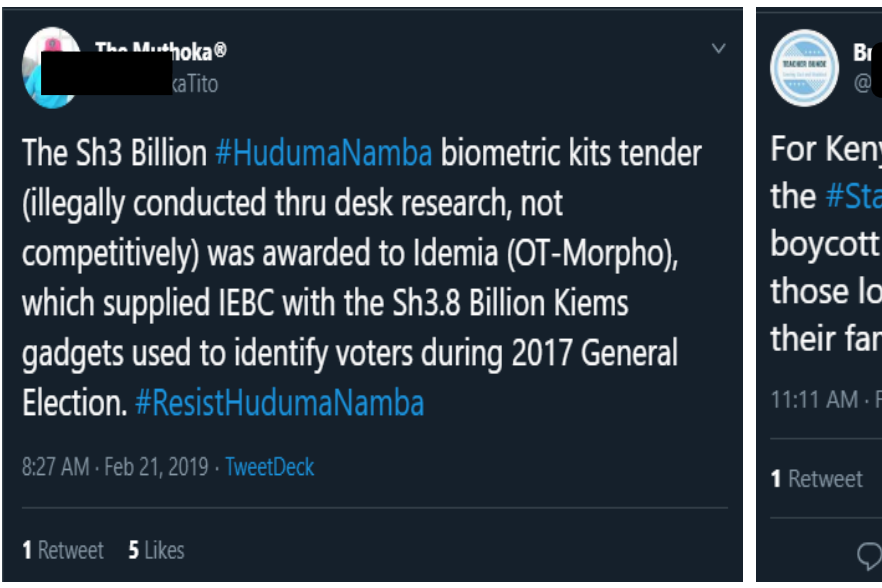

For Kenyans to show the anger and frustrations about the \#StateOfCorruption in this country, they should boycott and sabotage this \#HudumaNamba thing. Let those looting this country dry register themselves and their families. @Disembe @Asamoh_@DavidNdii

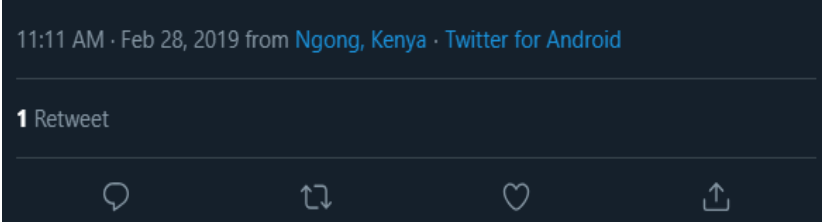

Fig. 1 A tweet showing displeasure with the procurement procedure during \#ResistHudumaNamba

\section{Presence of External Institutions}

The presence of multi-national companies in Kenya's technology environment has over the past years been treated with suspicion. Cambridge Analytica, for instance, had a strong presence during Kenya's elections period in 2013 and 2017, where it was reported to have manipulated public discourses in favour of certain candidates. Most of the multi-billion tenders involving infrastructural projects such as roads, railways, and housing projects are awarded to foreign companies. A few years ago, Huawei, a Chinese multinational was awarded a tender to install closed-circuit television cameras in three cities in Kenya - Nairobi, Mombasa, and Kisumu in what was the first project of the government surveillance program.

\section{Fatigue of constant registrations and surveillance}

Registration of persons has always been considered a colonial issue. As mentioned earlier, registration of persons in Kenya can be traced back to 1915 at the height of colonialism when the Native Registration Ordinance, as a piece of legislation, was created by the colonial administration. The legislation required individuals of 16 years or older to be issued with a small piece of paper that was locked in a metallic pocket and hang on the neck like a dog collar, and later came to be known as Kipande. The colonial government used this kind of identification to curtail freedom of movement and monitor the labour supply of the native Africans. In essence, the kipande was a surveillance tool for an indentured labour system which enabled the settler economy to suppress wages. Thus, this form of identification was seen to 


\section{AOR}

Selected Papers of \#AolR2019: The $20^{\text {th }}$ Annual Conference of the Association of Internet Researchers Brisbane, Australia / 2-5 October 2019

resemble a badge of slavery and sparked bitter protests. In the \#ResistHudumaNamba online protest, individuals considered Huduma Namba as a modern form of Kipande system.

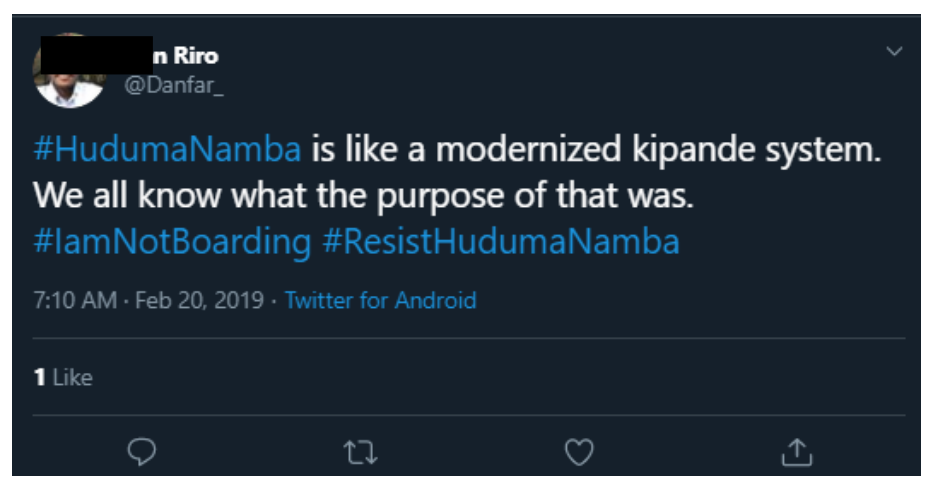

Fig. 2 : A tweet comparing the Huduma Namba to the Kipande system

With all these issues in mind and an existing level of fatigue with all these forms of registration traced back from the colonial era, online protesters considered it exhausting to have to register afresh for the Huduma Namba. Protesters saw this as a neo-colonial issue. The ideas in the Huduma were similar to the ideas of the colonial government. An era that citizens wanted to forget.

\section{Privacy, Surveillance, and Policing issues}

Huduma Namba was also established without existing laws on data protection and privacy issues. The existing laws are fragmented in various acts and policy papers. In 2018, the Kenyan government signed into law the Computer and Cybercrime Act. However, this law did not comprehensively deal with privacy violations, surveillance and censorship issues that exist in the country. Among other issues in the Act, it criminalizes interference with computer systems by third parties; the distribution of child pornography and online harassment like bullying and stalking; and the production of fake publications. The Penal code and the Kenya Information Communication Acts, where other ICT-related laws are found, do not cover data protection and surveillance issues for Huduma Number. In late 2019, the government developed Huduma Bill which made it mandatory for citizens to access government services 


\section{AOR}

Selected Papers of \#AolR2019: The $20^{\text {th }}$ Annual Conference of the Association of Internet Researchers Brisbane, Australia / 2-5 October 2019

\section{Conclusions and Recommendations}

This paper aimed at highlighting the main conversation that prompted the \#ResistHudumaNamba online protests. The case of \#HudumaNamba also reveals how the government continues to act with impunity.

In essence, Huduma Namba can be a successful program if done with an orderly and systematic way. The following recommendations could be useful.

i. They ought to first establish comprehensive legislation governing such biometric registrations.

a. The legislation should aim at protecting the public good

b. The public should be involved in deciding on the content of the legislation.

ii. The government should ensure that the procurement of such gadgets for biometric legislation is done with adherence to the existing laws to ensure quality

iii. Legislation of citizens should be done in a manner that ensures that there is no discrimination of individuals based on their religion, ethnicity, geographical location, class and

\section{References}

Gagliardone, I., \& Stremlau, N. (2011). Digital media, conflict and diasporas in the Horn of Africa. Open Society Foundations.

Kanyinga, K. (2009). The legacy of the white highlands: Land rights, ethnicity and the post-2007 election violence in Kenya. Journal of Contemporary African Studies, 27(3), 325-344.

Mukhongo, L. L. (2014). Negotiating the new media platforms: Youth and political images in Kenya. TripleC: Communication, Capitalism \& Critique. Open Access Journal for a Global Sustainable Information Society, 12(1), 328-341.

Tomchak, A.-M. (2015, January 22). \#FreeSpeechStories: Arrested for a tweet. BBC News. 